\title{
Why is the Eurozone in Crisis?
}

\author{
Gülen EImas Arslan
}

Department of Economics, Hitit University, Turkey

Copyright $(2015$ by authors, all rights reserved. Authors agree that this article remains permanently open access under the terms of the Creative Commons Attribution License 4.0 International License

\begin{abstract}
In this study, we will put emphasis on the EURO crisis, the biggest risk in the deepening of the world economy crisis which has ruled the world since 2008, this implementation's coming to a deadline and its results. We will primarily focus on the some questions such as why the EURO as the only money system didn't work out and what kind of risks may occur as it continues. In other words, the main aim of this study is to examine the back plan of the EURO crisis in terms of the economy theory and the implementation results of the countries within the system. Therefore, it can be thought that some answers can be given to the questions such as, why has the EURO practice come to a deadlock, whether the problem can be overcome, what are the scenarios about the consequence of the EURO and how will the world economy be affected as the Eurozone dissolves.
\end{abstract}

Keywords The Euro Crisis, Fiscal Deficit Problem in the Eurozone, Balance of Payments Problem in the Eurozone

\section{Introduction ${ }^{1}$}

As known in economic theory, classic protectionist foreign trade policy instruments are customs duty, quotas, import forbidding list and foreign exchange controls. Especially after 1980s when neo-liberal economic policies were widely accepted, the countries applying the protectionist policies have given up these implementations considerably. Moreover, the distance which ITO/GATT/WTO organizational structures passed has quite significant contribution over the liberalization of the world trade. To put it more briefly, after 1980, the late industrializing countries including Turkey which have adopted the industrializing strategies based on exportation, have given up the classic protectionist policies they have been applying, and therefore, they have been left with the exchange rate policy as the only one policy instrument for

\footnotetext{
${ }^{1}$ Thank you very much to Lecturer İlkay Pulan for corrections of English of this article.
}

exterior balance aim. However, especially after 1990s, it should be pointed out that this policy instrument has become dysfunctional due to the point where the short term capital movements has reached and these countries' short term external financing choice. From a different respect, the same situation is influential for the countries within the EURO zone. EU countries have completely given up the protectionist policies resulting from being a member of the Customs Union. Furthermore, they do not have an exchange rate policy in the situation of external deficit or external surplus resulting from being in the single money (EURO) zone. Under these circumstances, the question to be answered which stands as the major one in terms of usage of the Euro is that how the problem of the countries which have internal deficit or surplus will be solved. The second important question to be answered refers to the problem of how different implementations and conditions of the countries within the money zone on the issue of fiscal discipline will be overcome which stands as a significant subject creating disturbance between the countries within the EURO zone and risking the progression of the EURO.

In this study, while looking for answers to these questions on the basis of economic theory, the subject will be explained over its link with wars on reserve money and crises in the world economy. For this purpose, firstly, the classical protection policies and the importance of foreign exchange policies in case of their removal or reduction in terms of external balance will be briefly highlighted. Secondly, while briefly explaining the implementation of the EURO, the importance of fiscal discipline and the quality and significance of the external equilibrium problem in terms of continuation of the EURO application will be emphasized. Finally, the scenarios about the continuation of the EURO and the wars on reserve money in terms the world economy will be underlined and it will be questioned whether or not the current world economy crisis environment will be deepening if EURO crisis is not resolved.

\section{Theoretical Framework}

It is quite significant and critical to protect domestic industries for all industrialized and late industrializing 
economies. This subject is also a topic which never is off the agenda of the circles dealing with the economics. It is striking that all countries and all economists who have been trained in those countries presented different accounts regarding their different stages of their capitalist developments. United Kingdom, which is the first industrializing country, has always been a place that has defended the liberal economy and liberalism in international trade. Since it has many products having competitive advantage which have to be sold, and it has to buy raw materials to be used in production. There are the dominance protective tendencies and discourses in the countries of European Continent which are, on the one hand, in need of the products of United Kingdom, and on the other, they feel to keep their own industries against the powerful situation of United Kingdom products. Foremost among them refers to Frederic List from Germany. Alexander Hamilton from USA, who is in the same situation, defends the "baby industries thesis" which is based on the idea of keeping the newly developing industries in order to be able to compete with the foreign market. For example, "protection in strategical sectors" supports to protect huge, critical and vital industries in already industrialized economies [5: p.7]. Protection is very critical for all the economies but a well-known reality is the fact that in the periods when the protecting policies increased, the world economy decreased and otherwise expanded [12: pp. 268-272]. For example, it is a known fact that, in the years between the two World Wars when international protection policies and uncertainty in the international reserve money reached to extreme levels, the world economy decreased extremely. The famous the Great Depression of 1929 remarkably tightened world economy in those years. Thus, the countries came together even before the Second World War ends and started a work to liberalize the world economy. In order to develop a multilateral trade and payment system, it was aimed at determining the international reserve money on the one hand and establishing a steady and realist exchange rate system for liberalizing the world economy. As it is known, the IMF, the World Bank (IBRD) and the International Trade Organization -ITO- (this institution has not come into function and the GATT has carried the process until the World Trade Organization -WTO- was established in 1995) are the three institutional organization as the product of this process. In fact, it is not wrong to say that the EURO is a product of this process because the Bretton Woods system, which gave life to these three organizations and facilitated a fixed rate system ended in 1971- March 1973. However, Europe, eager to experience the advantage of clearness and specificity of a fixed rate regime, has continued to search for the fixed rate and this search facilitated the process creating the EURO. The EURO is one of the fixed rate regimes which has been applied after the collapse of the Bretton Woods's system by the EU member countries.

Consequently, the foreign trade liberalization efforts in terms of catching up the trend of liberalization of world economy has slowly but successfully reached an important point in the eyes of the GATT. On the other hand, the pressure of fierce global competition has accelerated the spirit and initiatives for economic solidarity even for developed economies. Among them, there was also the EU accession process for European countries who were attempting to capture a competitive advantage over other economies. Thus, while, on the one hand, there has been the progress of the GATT on the path toward liberalization; on the other, due to the allocation of full liberal trade in the EU itself and the matter of how they are going to overcome the external equivalence problem within themselves which they accessed through the application of a single currency, it has become a dead end between the countries for the countries in monetary union. The section containing one of the main problems about the issue on continuation of the EURO -how the countries within the system are going to overcome the external equivalence problem- will be handled in the next section.

\section{External Balance of Payments Deficit Problem of the Countries within EURO Implementation}

As we have mentioned earlier, the classical protective policies for foreign trade consist of customs duties, quotas, import prohibitive lists and foreign exchange controls. Among those policies, the most preferred one refers to the customs duty application which is a policy instrument that applies the custom duty to the imported product and enables the product to reach the consumer for a more expensive price as the custom duty itself (export price of the product + custom duty). Therefore, the domestic manufacturers in the internal market will have the opportunity to continue their manufacturing process up to this tax included price, and in this way, they will be able to maintain manufacturing process. The quota application aims at importing every product as required in accordance with priority product import. As for the import prohibitive lists are generally regulated and implemented in accordance to the prohibitions applied for luxury consumer goods or strategic and critical goods. As foreign exchange controls are concerned, inflow and outflow of foreign currency is performed through the central banks with the permission and knowledge of the official authorities. In this application, there is an attribute of the country's foreign exchange potential and allocation. Therefore, with regard to priority allocation of the country's foreign exchange potential, this policy tool is primarily used together with the quota and import prohibitive lists applications. There are many known positive and negative effects of these applications in the economic doctrines. The main negative effect of renunciation of these applications refers to lack of political tools rather than exchange rate in the hands of policy makers in case of chronic external deficit. Therefore, in the case of liberalization preference in foreign trade, the foreign exchange is becoming the single most important 
policy tool in terms of external equivalence objective. In other words, when there is external deficit, the foreign exchange is determined at such a point where, in order to provide external equivalence, it will be possible to make the export more expensive and the import more attractive. For instance, assume that the price of one pilot pen is 1 dollar. While 1 dollar $=1,5 \mathrm{TL}$, it will be manipulated in a way that 1 dollar $=1,8 \mathrm{TL}$. Thus, due to the erosion of the TL, while the importer will retract sue to the increase in price of $0.3 \mathrm{TL}$ per pen, the domestic manufacturers capable of production within this margin will be engaged in production. As for the exporter, who was previously chasing profit in the inner market of 1 dollar for the previous imported pens previously receiving $1,5 \mathrm{TL}$ - will now together with the increase will receive $1,8 \mathrm{TL}$. When the profit margins increase, the export has become more attractive for him.

However, the EU member states participated to the implementation of a single currency do not have any chances left for either classical protection policy tools or exchange policy tools applications mentioned above in the issue of external equivalence. Under these circumstances, the question to be answered remains as what these countries will be facing in the terms of chronic trade deficit and surplus.

Let's take as an example the two largest economies in the monetary system. Let's say one of them is Germany and the other one is France. Let's assume that France is in trade deficit (negative balance of payments) towards Germany. Due to being in the monetary system, in order to ensure external balance of payment, France has neither any classical protection tools nor exchange rate policy. In this case, the only way for France to ensure the external balance of payment is to reduce the incomes and price levels in France and to increase them in Germany. Thus, while in France the relative prices of export products are decreased, the chance to compete will be increased, while in Germany the opposite process will be experienced. Unfortunately, this is not possible for the market mechanism to ensure that at short and medium terms. Therefore, the policy makers in France have to develop an appropriate policy package in terms of income and price reduction.

Let's assume demands of the consumers towards German goods are increased in France for any reason. Initially the increase of the demand for German goods will have the following effects: as Germany cannot be the infinitely elastic supply curve, the amount will lead to an increase in production, and then the increase of the price. With this development, the relative price structure will change, and therefore, as the price will rise in Germany, the price will relatively decrease in France. However, as expected, this process is not as simple as pictured in theory. While the market forces by themselves are not enough to eliminate the foreign trade balance, the German policy makers should apply policies for further increase in the level of income and price. Likewise, France should apply a reverse policy to decrease the income and prices and to relatively cheapen the export goods. These policies will provide the mutual foreign trade balance betterment leading prices to decrease in France and causing inflation in Germany.

The economical problems which will manifest themselves in these two countries cannot be carried for a long period of time. This situation is invested with unpleasant characteristics for both countries. Therefore, there is another option available for ensuring the internal and external equivalence. It is possible to explain this option through optimum currency area [1 and 4]: In order to create optimum currency area, you have to be successful at four subjects two of which are of vital importance for the functioning of the system. While the first of them is the wage-price flexibility, the second one refers to labour movement flexibility. If these two conditions are met, than how will the transport mechanism operate in both countries? We expect that initially, a shift in demands (the decrease in demand for French goods) will reduce employment in France. If the prices and wages were flexible, the French workers who lost employment would be willing to work for lower wages for re-employment. While the decrease in prices would encourage greater production, France's aggregate supply curve would shift to the right. This would also mean a decrease in commodity prices and an increased chance of competition. Therefore, the demand for French goods would increase. The initially increase in demand towards the German goods in Germany would increase the demand for labour force, and would cause an increase in wages in Germany (which would be followed by the price increase), and consequently the aggregate supply curve would shift to the left.

Beside flexible wages, the increase of labour mobility as much as possible is also another way out. For instance, when unemployment reveals in France, if the French unemployed immigrated to Germany where there was a trend of increase in labour demand, this would block the rise of wages in Germany and the opposite would occur in France. This situation would adversely affect the process of job stability. However, there are unemployment benefits and some social supports in modern industrial societies. These supports carry the meaning that the unemployed also continues to be a part in the demand for goods. Therefore, migration of the unemployed from France to Germany causes a relative decrease in France's amount of demands compared to its production. The reduction in demand will create downward trend in prices, as well as an increase in export potential.

In conclusion, if the integration countries will have the wage/price flexibility and labour mobility, then they can adjust recoveries for equalising the foreign trade without France grappling with unemployment and Germany with inflation. However, it should be taken into consideration that neither the market mechanism has a magical wage/price flexibility nor is the full mobility of labour force applicable in real life. In as much as wages and prices are difficult to bring down and it should not be expected that the labour force within a certain age scale will be enthusiastic about migration.

Strictly speaking, today, one of the fundamental problems regarding the ongoing EURO sustainability problem as the 
subject of a serious debate is certainly associated with these issues. In economic theory, in order to define the EURO implementation as an optimum monetary zone, the wages/price flexibility must be on an advanced dimension, there must be full labour mobility; countries within the zone need to be each other's major trading partners and high rates of trade openness of economies are required [4]. Therefore, another scenario for providing sustainability of the EURO should be to cover much more distance in realizing an optimum monetary zone. However, expecting a short term realization and getting fast results out of this proposal would remain as a dream, as we will cover it in the section of how to overcome the crisis scenarios.

\section{Fiscal Discipline Problem in the EU}

In terms of the cost of public policies, it is known that the countries within the EURO zone continue to have different applications which create discomfort among themselves. Regarding implementation between countries, it is quite obvious that the gap between revenues and expenditures of the state budget is quite wide. The countries with a high budget deficit carry the process through continuous of borrowing markets. Due to the stockpiling of debt, the process have come reached a deadlock and those countries started to lose credibility in the international arena. This bill has dramatically turned towards the most powerful economies in the single monetary system. The following quote should explanatory in this regard:

"The mission of the Economic Stability and Growth Pact (SGP) is to help the union to consistently grow trough the co-ordination between monetary and fiscal policies. For this the public budget has to be balanced, i.e., it has adopted a policy of tight budgets. The SGP has are legitimate reasons for stipulating medium-and long-term budget equivalence. The first reason is that in cases a liberal recognition is given to the member states for budget expenditures, the implementation of their expansionary budget expenditures will create such an effect similar to the free-rider problem within the monetary union. This non-co-operative situation may cause proliferation of budget problems and may lead to an alienation from the optimal budget deficits within all of the monetary union (Echingereen, 2005:3-10; Bruni, 2004:37). The second reason is connected to the first one and is explained as Moral Hazard. The Moral Hazard here arises from the deficit bail-out guarantee of the budget deficit owners in the event of a crisis by other countries and / or the European Central Bank (ECB). This is ground-breaking development for the stability and continuity of the monetary union. Therefore, a strict budgetary discipline is stipulated SGP. SGP, with the with a prerequisite of achieving the goal of medium and long-term budget balance and in cases of facing a negative demand shock within the European Monetary
Union (EMU), and / or automatic stabilizers are activated (like a rise in the unemployment rate), it is allowing the use of expansionary budget expenditures without compromising of 3\% (Debt stock / GDP) accepted as Maastricht criteria. This is due to non-implementation of independent monetary policy in EMU member countries (Bruni 2004:37-4). The basic point that should be emphasized is that the co-ordination between the member states must be ensured.... [4:p.309].

However, as it is also known, when countries are accepted into the EURO implementation, they are followed up whether or not they meet the "Maastricht criteria" which also include financial criteria. Two of the Maastricht Criteria are closely linked to the fiscal disciplines of the member states. "Maastricht criteria" (1993) are the conditions that the member states need to fulfil in order to join the monetary union of the EU. Those are as follows:

1. Inflation rates must not be more than 1.5 percentage points higher than the average of the three best performing (lowest inflation) member states of the EU.

2. The ratio of the annual government deficit to gross domestic product (GDP) must not exceed 3\% at the end of the preceding fiscal year.

3. The ratio of gross government debt to GDP must not exceed $60 \%$ at the end of the preceding fiscal year.

4. Long-term interest rates: The nominal long-term interest rate must not be more than 2 percentage points higher than in the three lowest inflation member states.

When starting the implementation of the EURO, 11 union members which meet the criteria for compliance based on the reports from the European Monetary Institute and the European Council was adjudicated to be included to the monetary union. Those countries include Germany, Austria, Belgium, Finland, France, Holland, Ireland, Spain, Italy, Luxemburg and Portugal. England, Denmark and Sweden stayed out of the European Monetary Union as a result of their own preferences, while Greece at first was excluded from the European Monetary Union because they could not meet the compliance criteria, but was later on included to the monetary union. Nowadays, with the participation of other countries (Malta, South Cyprus, Slovenia, Slovakia, and Estonia), the number of the countries within the monetary zone reached to 17 countries.

The imperfect side of this implementation is that when countries were included into the monetary system, they were closely followed within the criteria framework. However, when they step away from the criteria after being accepted into the system, there is no return or sanctions applied related to the subject. In fact, nowadays most of the countries within the monetary system have considerable moved away from these criteria. For instance, when Eurozone crises appear in accordance to the end of 2010, we can see a sheet like follows when looking at the criteria "The ratio of the annual government deficit to gross domestic product (GDP) must not exceed $3 \%$ at the end of the preceding fiscal year": 
Ireland (-32,4\%), Greece (-10,5\%), Spain $(-9,2 \%)$, Portugal $(-9,1 \%)$, Slovakia $(-7.9 \%)$ and France $(-7,0 \%)$. These ratios are as follows in Union Members economies that stayed out of the monetary zone: The UK $(-10,1 \%)$, Poland $(-7.9 \%)$, Latvia $(-7,7 \%)$, Lithuania $(-7,1 \%)$.

Again for the same year, in regards to the debt must not exceed 60 percent of to GDP ratio criteria the situation is as follows: Greece (142,8\%), Italy $(119,0 \%)$, Belgium $(96,8 \%)$, Ireland $(96,2 \%)$, Portugal $(93,0 \%)$, Germany $(83,2 \%)$, France $(81,7 \%)$, Austria $(72,3 \%)$, Malta $(68,0 \%)$, The Netherlands (62,7\%), South Cyprus $(60,8 \%)$ and Spain $(60,1 \%)$. These ratios are as follows in Union Members economies that stayed out of the monetary zone: Hungary $(80,2 \%)$, The UK $(80.0 \%)$.

As observed in the results, many economies within the EU are considerably diverged from the criteria related to fiscal discipline. There are many challenges facing the re-provision of budgetary discipline. For instance, it is very difficult to reduce the public personnel expenditures within budget items of many European economies. In addition, the investment expenditure related to the development processes of the peripheral economies will be relatively higher. On the other hand, from the point of the European economies, the social policy priorities and the transfer expenditures compared to many contemporary economies are traditionally higher. This has also a legal ground supported by history in the European countries. For these reasons, it is possible to diversify the challenges standing in front of the budgetary discipline and alignment for other European economies.

Considering the last two sections, it is observed that nowadays many union member countries both suffer from the balance of payment deficit problems and face domestic deficit problems. Thus, the problem of twin deficit experienced in these countries is also recognized in the related literatures.

\section{Scenarios for the Continuation of the Euro and the World Economic Crisis}

In this chapter, it is planned to clarify the issue on reserve money and wars on reserve money. The chapter will continue with covering subjects such as the location of the EURO and its status as a reserve money, continuation of the EURO, how the EURO crisis is a big risk towards the deepening of the world crisis and scenarios for the fate of the EURO.

It should be stated that since the appearance of the Euro on the world market as a physical currency in 2002, its rapid acceptance as reserve money was resulted from a severe loss of confidence towards the dollar, which was serving as a reserve money at that time. The dollar has proved its mission as a reserve money in the international arena with the establishment of the international monetary system straight after the II World War. As it is known, this international monetary system process, which has engendered the IMF and the World Bank, collapsed with the obstruction between the years of $1971-$ '73. Nonetheless, just as the system's institutions, like the IMF and the World Bank, the dollar as the system's reserve money has continued to maintain its mission to the present day. However, the real economic factors that led to the collapse of the system are also the fundamental reasons for the emergence of the dollar crisis. Briefly, the economic weaknesses and structural problems behind the dollar as reserve money remain to be the fundamental problem for loss of confidence. The main reason for this loss of confidence is the massive external deficit of the USA. In order for reserve money to be good reserve money, it has to carry three basic characteristics described in the Economic Theory: The first one is the principle that "A good reserve money, no matter where in the world it should be generally accepted as means of payment". The second one is that the reserve money should carry well the mission to be the best value currency accumulating tool. As third, the reserve money needs to be joint accounts unite [11]. Therefore, it is important for reserve money to be stable. Nevertheless, due to the structural economic problems, balance of payment deficit and notably external deficits of the U.S.A. economy, the formation of the opinion that the dollar cannot be stable monetary is the main reason why it cannot carry the characteristics of a good reserve money since years. For this reason, the introduction of the EURO to the world market as reserve money is closely related to it. This rapid acceptance has caused the EURO to quickly gain value against the dollar as soon as entering the market. However, in fact, this rapid value gaining process has put a strain upon the economies of the EU. With gaining value of the Euro, The European economies which are in recession and which suffer from quite low growth has faced problems of weakening of competitiveness of export industries, cheapening of imports and growing of external deficit. This actually has become an instigative development for the recession process. Since there was already a recession, with the appreciation of the EURO, some importation and exportation industries residing in the state has been grappling with a shrinking process. Therefore, the implication of the monetary policies which make the dollar more valuable through interest rate policies primarily adopted by the USA, became a development that was also supported by the member countries. At this point, policy-makers in the United States have chosen to apply a basket policy, which subordinated the external balance and primarily aimed to strengthen the dollars location as reserve currency.

Herein, it needs to be stated out that there is a classical dilemma in economies behind the reserve currencies: if their currency is reserve money, it will provide two major advantages to them. The first one is that due to their currency accepted in worldwide, they will have the opportunity to finance their external deficits, if there are any, by monetise while other economies are able to provide this only through the cost of higher interest rates and sometimes by enduring currency premiums.

On the other hand, the other advantage that is granted to economies behind the reserve money is seignorage profit. 
However, the disadvantage of the economies behind the reserve money is that due to the fact that the reserve money's excessive appreciation, those economies lose their chances to compete, and in parallel to regression in the export industries, the occurrence of loss of momentum in economic growth. Therefore, when the USA felt uncomfortable about the throne of the dollar as reserve money was endangered by the EURO, they have increased the interest rates and they have supported for a while the appreciation for the dollar with the increasing demand even under the cost of the growth of the external deficits. The USA, while, on the one hand, it did not willingly give up the advantages of the dollar carrying the mission of being reserve money, on the other hand, it had to develop its economical policies in order to give priority to the external equivalence matter. The same dilemma stands for the European Region. While the countries within the monetary system want the EURO to be sitting on the reserve money throne, getting the advantages and wanting to take away these advantages from the dollar, they have also faced the risks of weakening of competitiveness in exports and of recession.

Today, the reserve money function is carried out by the dollar, the EURO and gold. The distancing of the gold from the reserve money function dates back to before the First World War. However, the gold still remains as a safe harbour whenever world economies engage into crisis periods. After 2007, when the world went into the economic crisis, gold became reserve money again and its value increased relatively. Even in this chaotic atmosphere, gold still remains to be the most reliable reserve money. In fact, the Eurozone is now somewhere beyond the reserve wars. Currently, the Europe is only focused on the continuation the EURO and it is far away from managing the war on reverse money on its advantage. For now, it seems that the arena is left first to the dollar and gold as the its close follower, and it seems like the EURO is retreated from the arena.

Then, why does it carry such a big importance for the world economy to get over the EURO crisis? The primary answer to that should be this: The EURO has managed to be a reserve currency for individuals, facilities and the central banks since the day it has entered the market. Therefore, disintegration of the EURO will negatively and deeply affect all countries and the economic actors. This would create a new fluctuation in the world which is already struggling with economic crisis, and inevitably all the economies would be dragged into chaos.

Thus, what are the scenarios for the continuation of the EURO?

Three scenarios on this issue are presented in the economic circles. One additional scenario has been added in this article to the existent ones. Suggestions on the search for a solution proposed by the EU also show that this new proposal could bring about functional results. The first scenario by the economical circles is to overcome the problems by covering more ground at the common currency area. As we stated before in the second and third sections of this paper, this is a proposal to provide an advanced integration of the required 4 basic conditions for establishing an ideal optimum monetary area. However, as mentioned above, this, in fact, is not a situation which can be achieved in a short term.

The second scenario is about greater economies, such as France and Germany, regarding leaving the zone and returning to their old currencies so that the peripheral economies can continue to the economical EURO application. However, it is very difficult to create a positive opinion for the applicability and sustainability of this proposal.

As for the third scenario, it is based on the removal of weak economies, such as Greece, which is also seen as the main reason for the EURO crisis. It is an expectable situation for the remaining strong economies to maintain the continuity of the EURO and thus, for the EURO to carry out a strong alternative reserve money mission to the world. It should be known that in the economic circles, this scenario is regarded as feasible and sustainable.

Finally, another scenario proposed only in this article is that the EURO continues its life like a physically present supranational reserve money (like as Keynes' "bancor" which was offered by Keynes at Bretton Woods negotiation in 1944) and that all the economies within the system turn back to their old currencies. Thus, the countries within the system will have the opportunity to relatively determine their own exchange rate policies and with the EURO as good reserve money, they will be also able to establish the stability of their own exchange currency within themselves [6].

Besides, the EU, with the EURO as strong reserve money, would be in a strong position among the wars on reserve money in international arena. In our opinion, this last scenario seems more possible and functional.

Thus, if we come back to the question that "Why does the continuation of the Euro carry such a crucial importance for the state of affairs in the world economy?"; this is an issue that has to be evaluated interrelatedly. Firstly, as we have emphasized before, it is related to the issue of the EURO being reserve money. As it is known the EURO is kept as reserve money by individuals, facilities and the central banks, and in cases which the value of the EURO decreases very fast or the issue of the EURO's failure comes to the agenda, these actors will experience a serious loss of wealth, and that is a serious risk for the world economy. Secondly, in the global world where the economies which are so intertwined, the problem regarding the continuation of the EURO in the European economies within the system would cause the suffering of all the economies. The world economy which is in the crisis since 2008, would be deeply affected by a negative development like this, and in this process which the crisis is extended over a long time period, a negative development regarding the EURO would only deepen the world economic crisis.

\section{Conclusions}

In the global world where the economies have intricate 
relations, the EURO crisis is the most important risk regarding the deepening of the world crisis. The Euro crisis has shown once again that the most important problem that the world economic system was facing historically is uncertainties related to the international monetary system and the reserve money. Nowadays, the reserve money mission is carried out by dollar, the EURO and gold. Therefore, the overcoming of the EURO crisis is of great importance. The first of the scenarios mentioned above might be a solution with a short-term nature, and the vision of promoting integration for leaving the crisis behind does not seem very realistically even for the EU itself. In the same way, the proposition which suggests separating the strong economies from the weak ones within the system in order to overcome the EURO crisis does not also seem realistic. Among these scenarios, the most functional one is the planning of a new alternative international monetary system and the reserve money for the Europe. However, although this scenario is still very unformed in the minds of the European countries, it is considered that the proposal for removal of the European Financial Stability Fund (EFSF), the European Stability Mechanism and Eurobond is among the developments that will develop this scenario and serve to shape this project.

The deepening of the EURO crisis is also a risk for Turkey. In fact, besides Turkey is adversely affected by the deepening of the world economic crisis in an indirect way, it is inevitable to be directly and deeply affected by crises of the European economies as well since Europe is an important trading partner.

That is why, the world is in crisis and Turkey with its short-term financing economy is following the Euro crisis closely and with concerns. Consequently, both Turkey and the world must make very good predictions about the process related to the EURO crisis and should be prepared to develop appropriate policy baskets.

\section{REFERENCES}

[1] Aktan, Okan. Theory of Optimal Currency Area and European Monetary System, Hacettepe University Publication, no: 4, Ankara, 1983.

[2] Bruni, Franco. "Fiscal Discipline in a Monetary Union: Issues for the Euro Area. European Monetary and Financial Integration", SUERF Studies, No: 2, 2004.

[3] De Grauwe, Paul. "Crisis in The Eurozone and How to Deal with It", CEPS, no: 204, February, 2010.

[4] Demirel, Baki. Theory of Optimal Currency Area and What will Espect Türkish Economy When joining EURO Zone, Thesis of Phd, Gazi Üniversity, S.B.E., Ankara, 2011.

[5] Elmas, Gülen. Effects of to be Member of Customs Union on Turkish Economic Price System, Thesis of Phd, Gazi Üniversity, S.B.E., Ankara, 1998.

[6] Elmas Arslan, Gülen. "Why is Euro Implementation in Crisis?" ASOMEDYA / BÜYÜTEC, Ankara Chamber of Industry Publication, January/Fabuary 2013 Sayıs1, pp:53-62, 2013.

[7] European Commission. "Special Report: Understanding The Crisis in Europe", European Commission Directorate General for Economic and Financial Affairs, European Economy Research Letter, Vol. 3, Issue. 3, December 2009.

[8] Mc Kinnon, Ronald. "Mundell, the Euro and Optimum Currency Areas", Journal of Policy Modelling, vol. 22, no. 3, pp: 311-324, 2000.

[9] Mishkin, S., Frederic, The Economics of Money, Banking and Financial Markets, Addison Wesley, Boston, 2007.

[10] Mundell, Robert. "Currency Areas, Volatility and Intervation", Journal of Policy Modelling, vol. 22, no: 3, pp. 281-299, 2000.

[11] Özbek, Dilek, International Monetary Systems, İmaj Publication, Ankara, 1999.

[12] Walther, Ted. World Economy,_Translator: Ü.Çağlar, Alfa Publication, İstanbul, 2002.

[13] Warin, Thierry, "The Euro at 10: Successes and Challenges", CIRANO, Burgundy Report, 2009 RB-05, May 2009. 